\title{
Effect of varying experimental conditions on the viscosity of $\alpha$-pinene derived secondary organic material
}

\author{
James W. Grayson ${ }^{1}$, Yue Zhang ${ }^{2}$, Anke Mutzel $^{3}$, Lindsay Renbaum-Wolff ${ }^{1, a}$, Olaf Böge ${ }^{3}$, Saeid Kamal ${ }^{1}$, \\ Hartmut Herrmann ${ }^{3}$, Scot T. Martin ${ }^{2,4}$, and Allan K. Bertram ${ }^{1}$ \\ ${ }^{1}$ Department of Chemistry, University of British Columbia, 2036 Main Mall, Vancouver, BC, V6T 1Z1, Canada \\ ${ }^{2}$ School of Engineering and Applied Sciences, Harvard University, Cambridge, MA 02138, USA \\ ${ }^{3}$ Leibniz-Institut für Troposphärenforschung e.V. (TROPOS), Permoserstr. 15, Leipzig 04318, Germany \\ ${ }^{4}$ Department of Earth and Planetary Sciences, Harvard University, Cambridge, MA 02138, USA \\ anow at: Boston College, 140 Commonwealth Avenue, Chestnut Hill, MA 02467, USA, and Aerodyne Research Inc., \\ 45 Manning Rd, Billerica, MA 01821, USA
}

Correspondence to: Allan K. Bertram (bertram@chem.ubc.ca)

Received: 20 October 2015 - Published in Atmos. Chem. Phys. Discuss.: 24 November 2015

Revised: 3 March 2016 - Accepted: 19 April 2016 - Published: 18 May 2016

\begin{abstract}
Knowledge of the viscosity of particles containing secondary organic material (SOM) is useful for predicting reaction rates and diffusion in SOM particles. In this study we investigate the viscosity of SOM particles as a function of relative humidity and SOM particle mass concentration, during SOM synthesis. The SOM was generated via the ozonolysis of $\alpha$-pinene at $<5 \%$ relative humidity (RH). Experiments were carried out using the poke-and-flow technique, which measures the experimental flow time ( $\tau_{\text {exp, flow }}$ ) of SOM after poking the material with a needle. In the first set of experiments, we show that $\tau_{\text {exp, flow }}$ increased by a factor of 3600 as the RH increased from $<0.5 \mathrm{RH}$ to $50 \% \mathrm{RH}$, for SOM with a production mass concentration of $121 \mu \mathrm{g} \mathrm{m}^{-3}$. Based on simulations, the viscosities of the particles were between $6 \times 10^{5}$ and $5 \times 10^{7} \mathrm{~Pa}$ s at $<0.5 \% \mathrm{RH}$ and between $3 \times 10^{2}$ and $9 \times 10^{3} \mathrm{~Pa}$ at $50 \% \mathrm{RH}$. In the second set of experiments we show that under dry conditions $\tau_{\text {exp flow }}$ decreased by a factor of 45 as the production mass concentration increased from 121 to $14000 \mathrm{\mu g} \mathrm{m}^{-3}$. From simulations of the pokeand-flow experiments, the viscosity of SOM with a production mass concentration of $14000 \mu \mathrm{g} \mathrm{m}^{-3}$ was determined to be between $4 \times 10^{4}$ and $1.5 \times 10^{6} \mathrm{~Pa}$ s compared to between $6 \times 10^{5}$ and $5 \times 10^{7} \mathrm{Pas}$ for SOM with a production mass

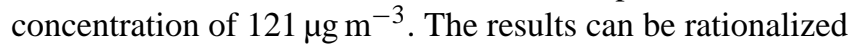
by a dependence of the chemical composition of SOM on production conditions. These results emphasize the shifting characteristics of SOM, not just with RH and precursor type,
\end{abstract}

but also with the production conditions, and suggest that production mass concentration and the $\mathrm{RH}$ at which the viscosity was determined should be considered both when comparing laboratory results and when extrapolating these results to the atmosphere.

\section{Introduction}

Aerosol particles are ubiquitous in the Earth's lower atmosphere, of which a major source is the oxidation of volatile organic compounds (VOCs; Andreae and Crutzen, 1997). VOCs are emitted from the Earth's surface by both human and natural sources and, once in the atmosphere, are readily oxidized to form secondary organic material (SOM) that can condense to the particle phase (Hallquist et al., 2009). Aqueous-phase reactions also provide an important pathway to the production of SOM (Ervens et al., 2011).

Atmospheric particles containing SOM play an important role in governing the Earth's energy budget, both directly via the scattering or absorption of solar radiation (Yu et al., 2006) and indirectly by acting as cloud condensation nuclei (Solomon et al., 2007) and possibly as ice nuclei (Berkemeier et al., 2014; Choularton et al., 2007; Knopf and Rigg, 2011; Ladino et al., 2014; Wang et al., 2012b; Murray et al., 2010; Schill et al., 2014). SOM particles may also play a role in human health (Baltensperger et al., 2008) and the chemistry of 
the atmosphere by providing solid or liquid phases for reactions (Hallquist et al., 2009). Despite the importance of SOM particles, many of their physical properties, such as viscosity, are poorly understood.

The viscosity of SOM is important for a number of reasons. First, the viscosity of SOM governs the rate at which organic molecules can diffuse through particles, and knowledge of the viscosity is thus required to predict the mechanism, rate of growth, total mass, and size of modelled particles (Riipinen et al., 2011; Shiraiwa et al., 2011; Shiraiwa and Seinfeld, 2012; Shiraiwa et al., 2013; Zaveri et al., 2014). Viscosity is also important for predicting the longrange transport of polycyclic aromatic hydrocarbons (Zelenyuk et al., 2012; Zhou et al., 2012), as well as rates of both heterogeneous and photochemical processes (Houle et al., 2015; Kuwata and Martin, 2012; Lignell et al., 2014; Zhou et al., 2013). In addition, if viscosities are high in particles containing SOM the optical properties of the particles may be altered (Adler et al., 2013; Robinson et al., 2014), and both the crystallization of inorganic salts (Bodsworth et al., 2010; Murray and Bertram, 2008; Song et al., 2012) and the ability of particles to uptake water (Bones et al., 2012; Hawkins et al., 2014; Lu et al., 2014; Price et al., 2014; Tong et al., 2011) may be inhibited. Furthermore, if SOM particles are solid or "glassy" in phase under atmospheric conditions they may provide a surface for ice nucleation (Baustian et al., 2013; Berkemeier et al., 2014; Knopf and Rigg, 2011; Ladino et al., 2014; Wang et al., 2012b; Murray et al., 2010; Schill et al., 2014).

Researchers have traditionally assumed particles containing SOM to be of low viscosity when modelling particle growth (Hallquist et al., 2009). However, recent measurements have suggested that this may not be the case under certain conditions. Measurements that have suggested SOM can have high viscosities include (1) direct measurements of viscosity of SOM or proxies for SOM (Booth et al., 2014; Renbaum-Wolff et al., 2013; Pajunoja et al., 2014; Song et al., 2015; Zhang et al., 2015), (2) measurements of diffusion rates and mixing times in SOM (Abramson et al., 2013; Loza et al., 2013; Perraud et al., 2012), (3) bounce measurements off surfaces (Bateman et al., 2015; Kidd et al., 2014; Saukko et al., 2012; Virtanen et al., 2010, 2011), (4) measurements of the flatness of particles after impaction (O'Brien et al., 2014), (5) measurements of rates of evaporation from SOM (Cappa and Wilson, 2011; Vaden et al., 2011), and (6) measurements of reactivity of SOM (Kuwata and Martin, 2012; Wang et al., 2012a, 2015). Nevertheless, the viscosities and diffusion rates of SOM are still a matter of debate (Saleh et al., 2013; Robinson et al., 2013; Yatavelli et al., 2014; Price et al., 2015).

Recently we investigated the viscosity of the water-soluble component of SOM produced from the ozonolysis of $\alpha$ pinene in an environmental chamber (Renbaum-Wolff et al., 2013). The current manuscript is an extension of the work by Renbaum-Wolff et al. (2013). Similar to Renbaum-Wolff we study the viscosity of SOM particles derived via the ozonolysis of $\alpha$-pinene; however, in contrast, the current study focuses on particles consisting of the whole SOM, meaning both the water-soluble fraction and water-insoluble fraction.

In the first set of experiments, we investigated the viscosity of the whole SOM as a function of the relative humidity at which the viscosity was measured. In all cases the SOM was generated via the ozonolysis of $\alpha$-pinene under dry conditions, and hence the effect of relative humidity on the SOM chemistry was not explored. Reported here are viscosity measurements at RH values between $<0.5$ and $50 \%$ $\mathrm{RH}$, using SOM with production mass concentrations of 520 and $121 \mu \mathrm{g} \mathrm{m}^{-3}$. The results add to the few existing measurements of the effect of RH on the viscosity of SOM produced via the ozonolysis of $\alpha$-pinene (Renbaum-Wolff et al., 2013; Bateman et al., 2015; Kidd et al., 2014; Zhang et al., 2015). Understanding the effect of RH on the viscosity of SOM is important as RH in the boundary layer regularly varies between roughly 20 and $100 \%$ RH with varied time and location in the planetary boundary layer (Hamed et al., 2011).

In the second set of experiments, we investigated the effect on viscosity of the production mass concentration of SOM particles (in units of micrograms of SOM per $\mathrm{m}^{3}$ of gas) used when generating SOM. Experiments have shown that the composition of SOM particles can change with production mass concentration (Shilling et al., 2009), possibly affecting the viscosity of the SOM particles. The production mass concentrations of the SOM in the current study ranged from 121 to $14000 \mu \mathrm{g} \mathrm{m}^{-3}$.

\section{Experimental}

SOM particles were produced either in a flow tube (particle mass concentrations of 520 to $14000 \mu \mathrm{g} \mathrm{m}^{-3}$ ) or a chamber (particle mass concentrations of 121 and $230 \mu \mathrm{g} \mathrm{m}^{-3}$ ) at $<5 \% \mathrm{RH}$ and collected on hydrophobic substrates with an impactor (Sects. 2.1 and 2.2). The poke-and-flow technique in conjunction with simulations of fluid flow was used to determine the viscosity of the SOM (Sects. 2.3 and 2.4).

\subsection{Production and collection of SOM generated at production mass concentrations from $\mathbf{5 2 0}$ to $14000 \mu \mathrm{g} \mathrm{m}^{-3}$}

For the production of SOM at production mass concentrations from 520 to $14000 \mu \mathrm{g} \mathrm{m}^{-3}$, a previously described flow tube was used (Shrestha et al., 2013) to generate the SOM. Alpha-pinene (Sigma-Aldrich, $\geqslant 99.5 \%$ purity, $97 \%$ enantiomeric excess) and 2-butanol (Sigma-Aldrich, $\geqslant 99.5 \%$ purity; used as an $\mathrm{OH}$ scavenger) were introduced into the flow tube at an $\alpha$-pinene :2-butanol ratio of $1: 49$, using a dry air flow rate of $0.50 \mathrm{sLpm}$. Ozone was produced prior to the inlet of the flow tube by passing dry air through an ozone generator (Jetlight, Model 600) at a rate of $3.0 \mathrm{sLpm}$, result- 
Table 1. Conditions used for generating and collecting samples of SOM generated via the ozonolysis of $\alpha$-pinene. The whole SOM (both water soluble and water insoluble component of the SOM) was collected.

\begin{tabular}{lrrrrr}
\hline Sample name & $\begin{array}{r}\text { Samples } \\
\text { studied }\end{array}$ & $\begin{array}{r}\text { Production mass } \\
\text { concentration } \\
\left(\mu \mathrm{g} \mathrm{m}^{-3}\right)\end{array}$ & $\begin{array}{r}\text { Mode } \\
\text { diameter } \\
(\mathrm{nm})\end{array}$ & $\begin{array}{r}\text { Geometric } \\
\text { standard } \\
\text { deviation }\end{array}$ & $\begin{array}{r}\text { Collection } \\
\text { time (min) }\end{array}$ \\
\hline Flow tube sample \#1 & 3 & $(1.4 \pm 0.1) \times 10^{4}$ & $265 \pm 7$ & 1.43 & 20 \\
Flow tube sample \#2 & 3 & $(5.9 \pm 0.7) \times 10^{3}$ & $194 \pm 5$ & 1.47 & 90 \\
Flow tube sample \#3 & 3 & $(3.4 \pm 0.1) \times 10^{3}$ & $163 \pm 2$ & 1.46 & 150 \\
Flow tube sample \#4 & 3 & $(1.2 \pm 0.2) \times 10^{3}$ & $121 \pm 8$ & 1.46 & 450 \\
Flow tube sample \#5 & 3 & $(5.2 \pm 0.2) \times 10^{2}$ & $132 \pm 2$ & 1.52 & 800 \\
Chamber sample \#1 & 2 & $(2.3 \pm 0.1) \times 10^{2}$ & $181 \pm 12$ & & 95 \\
Chamber sample \#2 & 2 & $(1.2 \pm 0.1) \times 10^{2}$ & $169 \pm 12$ & & 180 \\
\hline
\end{tabular}

ing in an ozone concentration of $12 \mathrm{ppm}$ at the inlet of the flow tube, as measured by an ozone sensor (Ecosensors, UV100). Residence time in the flow tube was $38 \pm 1 \mathrm{~s}$, giving an $\mathrm{O}_{3}$ exposure $\left(\mathrm{O}_{3}\right.$ concentration $\times$ time $)$ of $456 \mathrm{ppm} \mathrm{s}$. For comparison purposes the background concentration of $\mathrm{O}_{3}$ in the atmosphere is $30 \mathrm{ppb}$, and assuming a reaction time of $1 \mathrm{~h}$ an exposure of $110 \mathrm{ppm} \mathrm{s}$ is calculated. The concentration of the $\alpha$-pinene entering the flow tube was varied to produce samples at a total of five different particle mass concentrations (as measured using an SMPS; TSI, model 3934), with the ozone concentration being kept in constant excess. Table 1 shows the mass concentrations and collection times used in the flow tube experiments, as well as the mean geometric size of the particles produced in the flow (Sample names Flow tube \#1-Flow tube \#5).

After exiting the flow tube the $2 \mathrm{Lpm}$ of dry flow was diluted with an $8 \mathrm{Lpm}$ flow of humidified air, giving a total airflow of $10 \mathrm{Lpm}$ with a humidity of $68 \pm 2 \% \mathrm{RH}$, as measured using an RH meter (Rotronic, HC2-S). The airflow then passed through a single stage impactor (MSP Corp.), within which a hydrophobic glass substrate was mounted. Over the course of an experiment sub-micron sized SOM particles impacted on a hydrophobic glass substrate, with the humidified gas serving to reduce the fraction of particles that bounced in the impactor. Over time the particles coagulated to form super-micron sized particles. The loss of some volatile components during the humidification cannot be ruled out. Loss of volatile components in the impactor should be relatively minor since the impactor used for collection has a small pressure drop ( $20 \%$ or less). The production mass concentration, mode diameter, geometric standard deviation, and collection times are detailed in Table 1. After collection, the samples were stored at $253 \mathrm{~K}$ until use. All samples were used within 4 weeks of production. To determine the impact of storing samples at $253 \mathrm{~K}$, the viscosity of one sample (produced using a mass concentration of $6000 \mu \mathrm{g} \mathrm{m}^{-3}$ ) was measured first after 4 days of storage and again after 24 further days of storage. The measured lower and upper limits of viscosity dif- fered by $<20 \%$ (which is within experimental uncertainty) when measured at both 30 and $<0.5 \%$ RH.

\subsection{Production and collection of SOM generated at production mass concentrations of 121 and $230 \mu \mathrm{g} \mathrm{m}^{-3}$}

For production mass concentrations $<500 \mu \mathrm{g} \mathrm{m}^{-3}$ the time required to collect enough material for the poke-and-flow experiments was $>12 \mathrm{~h}$ using the flow tube setup described above. As a result, to collect SOM using production mass concentrations less than $500 \mu \mathrm{g} \mathrm{m}^{-3}$ we used the Leipzig Aerosol Chamber (LEAK), a cylindrical $19 \mathrm{~m}^{3}$ Teflon bag (Iinuma et al., 2009). The LEAK chamber could be sampled at higher flow rates than the flow tube $(16 \mathrm{Lpm}$ as opposed to $2 \mathrm{Lpm}$ ), reducing the required collection time.

First, ozone was introduced into LEAK, which was operating under dry conditions $(<5 \% \mathrm{RH})$. The ozone concentration was held between 64 and 72 ppb (ozone monitor; 49c Ozone Analyzer, Thermo Scientific, USA). Afterwards $\alpha$ pinene (Sigma-Aldrich, $\geqslant 99.5 \%$ purity, $97 \%$ enantiomeric excess) was injected into LEAK, and the formation and growth of SOM particles within LEAK was monitored using an SMPS (TROPOS-type). No OH scavenger was used during experiments. After $80 \mathrm{~min}$ of reaction, giving an $\mathrm{O}_{3}$ exposure of 300-350 ppm s, the submicron-sized particles were collected by pumping air from the chamber at a flow rate of $16 \mathrm{Lpm}$. At the exit of LEAK the air passed through a humidifier unit (FC300-1660-15-LP-01, Perma Pure LLC, NJ, USA), and upon exiting the humidifier unit the air was determined to be at $91 \pm 2.5 \% \mathrm{RH}$, as measured using a handheld RH meter (RH85, Omega, USA). The airflow then passed through a single stage impactor, as described in Sect. 2.1. Particles collected and coagulated on a hydrophobic slide located with the impactor. As for before, the loss of some volatile components during humidification prior to collection cannot be ruled out, whilst the loss of volatile components in the impactor are expected to be relatively minor. After collection, the samples were stored at $253 \mathrm{~K}$ until use. All samples were used within 10 weeks of production. The produc- 


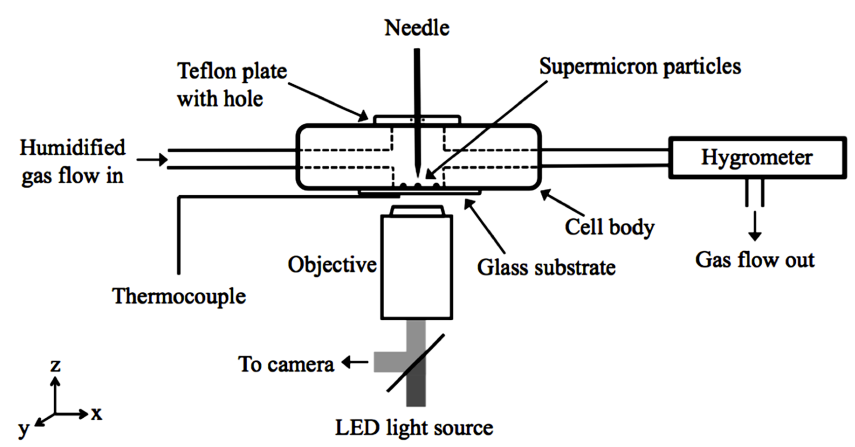

Figure 1. Schematic representation of poke-and-flow experimental setup.

tion mass concentration, mode diameter, geometric standard deviation, and collection times are detailed in Table 1 (samples named Chamber sample \#1 and Chamber sample \#2)

\subsection{Poke-and-flow technique}

A schematic of the setup for the poke-and-flow experiments is shown in Fig. 2. The technique builds upon the qualitative technique described by Murray et al. (Murray et al., 2012) and has been described in detail previously (Grayson et al., 2015; Renbaum-Wolff et al., 2013). In short, a hydrophobic glass slide, containing super-micron sized particles, was placed in a flow cell, and the flow cell mounted to a microscope. Experiments were performed at 293-295 K, with the temperature of the cell being monitored throughout by a thermocouple located directly beneath the slide surface. A flow of gas was passed through a bubbler located in a temperature-controlled water bath prior to entering the cell, allowing control over humidity in the cell. The dewpoint of the gas was measured by a dewpoint monitor (General Eastern; Model 1311DR), which was positioned at the exit of the flow cell. The dewpoint monitor was calibrated using the deliquescence dewpoint of potassium carbonate, and found to give readings within $0.1 \mathrm{~K}$ of the expected value at $43 \% \mathrm{RH}$. Each sample of particles on a substrate was allowed to equilibrate in the flow cell for $30 \mathrm{~min}$ prior to poke-and-flow experiments to ensure the particles reached thermal equilibrium with their surroundings after removal from storage at $253 \mathrm{~K}$.

A sharp, sterilized needle was attached to a micromanipulator, which could move the needle in the $x, y$, and $z$ axes. The needle was aligned vertically above a particle, typically $50-70 \mu \mathrm{m}$ in diameter, and then moved downwards along the $z$ axis, passing through the particle and impacting the substrate surface. Upon removal of the needle the behaviour of the particle was observed via reflectance optical microscopy and recorded using a charge coupled device (CCD).

In the majority of cases the penetration and removal of the needle resulted in the material of the particle forming a half-torus geometry (see Fig. $4 \mathrm{a} 2$ for an example). Over time the material flowed, and the area of the hole at the centre of the half-torus decreased. Ultimately, the depression filled and the particle re-attained its initial, energetically favourable, roughly hemi-spherical geometry. From the images the area A of the depression was determined. An equivalent area diameter $\mathrm{d}$ was determined from the equation $d=(4 A / \pi)^{1 / 2}$. The experimental flow time, $\tau_{\text {exp,flow }}$, was the time at which the equivalent area diameter decreased to half its original size. Though the value of $\tau_{\text {exp,flow }}$ is also dependent on physical properties other than viscosity, such as particle size, the values reported here are the raw values (i.e., no corrections have been applied to take account of particle dimensions).

During poke-and-flow experiments the SOM was exposed to a dry or humid gas flow over a period of 3-15 h. During this time semi-volatile components of the SOM may undergo evaporation. If the semi-volatile components were behaving as plasticizers within the SOM, the viscosity of the SOM may change. To determine whether this process occurred here and, if so, whether it had a significant effect on the results, the volumes of particles consisting of whole SOM and produced with a mass concentration of $6000 \mu \mathrm{g} \mathrm{m}^{-3}$ were determined for up to $45 \mathrm{~h}$ while exposed to a dry $(<0.5 \% \mathrm{RH})$ flow of nitrogen gas (see Sect. S1 in the Supplement for further experimental details). Within experimental uncertainty the volume of the particles remained unchanged (Fig. S1 in the Supplement).

In addition, the viscosity of particles consisting of whole SOM and produced with a mass concentration of $6000 \mu \mathrm{g} \mathrm{m}^{-3}$ was determined after both 1 and $45 \mathrm{~h}$ of exposure to a dry $(<0.5 \% \mathrm{RH})$ flow of nitrogen gas. The mean lower and upper limits of viscosity were determined to be roughly double after $45 \mathrm{~h}$ of exposure compared to their values after $1 \mathrm{~h}$ of exposure (Table S1 in the Supplement). In the Supplement (Sect. S1 and Table S2) we also show, using the Arrhenius mixing rule, that this small increase in viscosity could be due to evaporation of a small amount of semi-volatile material during the exposure to dry nitrogen, with the volume of the evaporated material being below the detection limit of the measurements of particle volume, but enough to result in a small increase in viscosity. Alternatively, oligomerization or polymerization, such as via condensation (e.g. Reinhardt et al., 2007), could occur within the samples at room temperature, with the products of this process being of higher viscosity than their precursors. This doubling in viscosity should be considered as a conservative upper limit to the effect of evaporation in the rest of the experiments reported here, which were carried out on a time scale of 3-15 h.

Two or three samples were analysed per set of conditions, and the results of the three samples combined to give the values reported here. In total, this study contains the results from experiments on a total of 436 particles. 


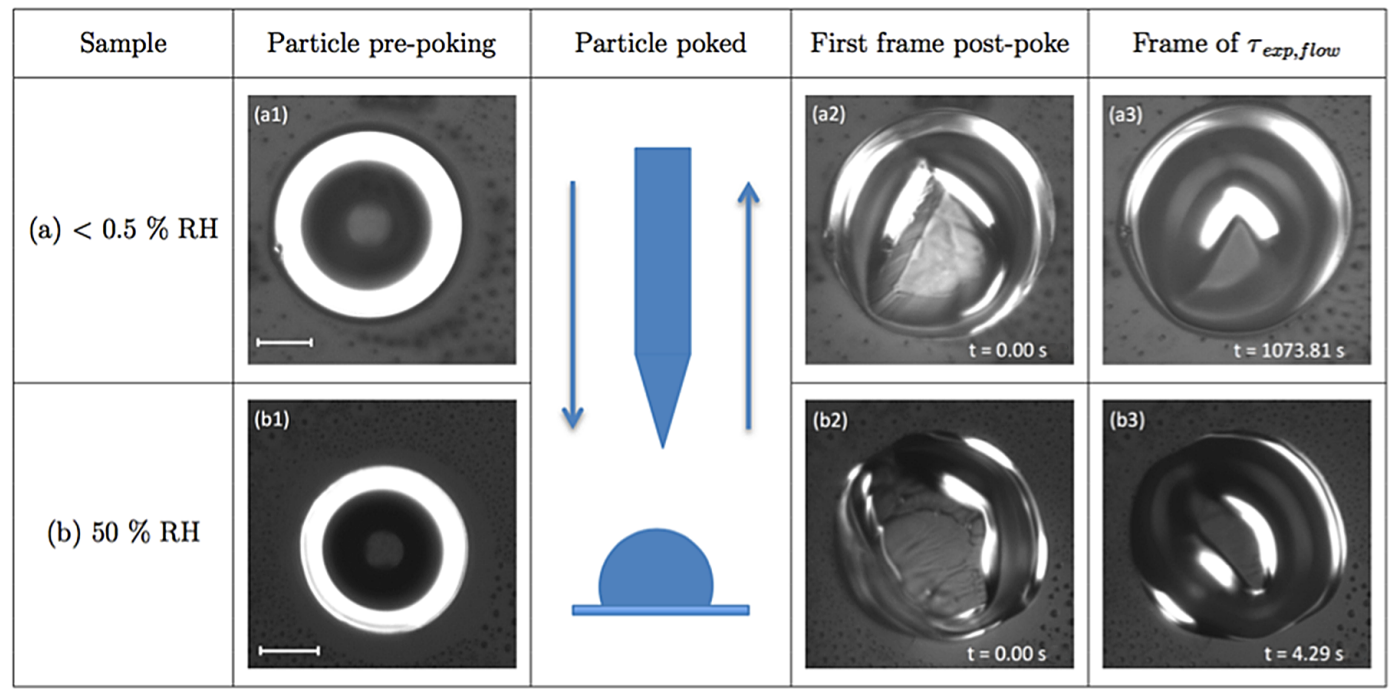

Figure 2. Optical images recorded during typical poke-and-flow experiments of whole SOM produced at a production mass concentration of $520 \mathrm{\mu g} \mathrm{m}^{-3}$ being poked at (a) $<0.5 \%$, and (b) $50 \%$, RH. Panels (a1) and (b1) correspond to SOM prior to poking. Panels (a2) and (b2) correspond to the first frame post-poke (i.e. the first frame after the needle has been removed). Panels (a3) and (b3) correspond to images of the experimental flow time, $\tau_{\exp }$, flow, the point at which the diameter of the hole at the centre of the torus has decreased to $50 \%$ of its original size. Scale bar in panels (a1) and (b1): $20 \mu \mathrm{m}$.

\subsection{Simulations of fluid flow}

Limits of viscosity were determined via simulation for each particle using the microfluidics module of COMSOL, a multiphysics program. Particles that exhibited flow were simulated using a half-torus geometry. Full details are shown in Fig. 2 of Grayson et al. (2015). The top and sides of the halftorus geometry, which represented the air-SOM interface, were allowed to undergo free deformation in all directions. The bottom of the half-torus geometry, which represented the SOM-hydrophobic glass interface, was allowed to undergo free deformation only in the horizontal plane. In the simulations the material flowed to minimize the surface energy, as was observed to occur in the experiments. For the simulations a mesh consisting of $\approx 5800$ elements and a mesh spacing of 3.92-337 nm was used, with the range in values of mesh spacing being required to accurately model the shape of the half torus, as well as track its movement over time. The model flow time, $\tau_{\text {model,flow }}$, was determined to be the time at which the diameter of the hole at the centre of the halftorus decreased to half its original size, with simulations per-

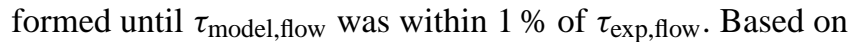
prior observations of Newtonian behaviour in sucrose-water solutions Hosny et al. (2013); Saggin and Coupland (2004), which are commonly used as proxies for SOM, the SOM was assumed to be Newtonian in nature for simulations.

Simulations were performed using estimates of the physical properties of SOM (i.e., particle-substrate slip length, surface tension, particle-substrate contact angle, and density; Table S3). In addition images of each experiment were used to determine the dimensions of each particle and its value of $\tau_{\text {exp,flow }}$. Contact angles were determined using 3-D images of the super-micron particles suspended on hydrophobic surfaces using a confocal fluorescence microscope (Leica SP5 II, with an excitation wavelength of $458 \mathrm{~nm}$ ) with a $20 \times$ objective, a schematic of which is shown in Fig. S2a. A $z$ stack series of images with a step size of $0.5 \mu \mathrm{m}$, was acquired for each particle. Contact angles were subsequently measured from the 2-D cross-sections in the $y-z$ plane using the LB-ADSA plugin for ImageJ (Fig. S2b). Contact angles were determined by measuring multiple particles from each sample and are reported in Table S4. The values used during simulations of a given particle are those determined for particles of the corresponding sample.

The main source of uncertainty in the viscosity of the SOM arises from uncertainty in the physical properties of SOM that are used in simulations, including the slip length, the particle-substrate contact angle, and the surface tension at the particle-gas interface. The variability in viscosity from particle to particle was only a small component of the overall uncertainty (discussed further in Sect. S2).

\section{Results and discussion}

\subsection{Effect of relative humidity on the viscosity of SOM}

The effect of relative humidity on the viscosity of SOM was determined for SOM produced with production mass concentrations of 520 and $121 \mu \mathrm{g} \mathrm{m}^{-3}$. Shown in Fig. 2 are images of SOM produced in the flow tube with a production mass concentration of $520 \mu \mathrm{g} \mathrm{m}^{-3}$ and studied at $<0.5$ and $50 \%$ 
RH. Shown in Fig. 2a1-a3 is SOM being studied at $<0.5 \%$ $\mathrm{RH}$. Prior to poking the SOM is in a hemispherical geometry (Fig. 2, Panel a1). The act of poking the SOM with the needle led to the formation of a half-torus geometry (Fig. 2, Panel a2). Upon removal of the needle the material flowed and the hole began to close, with a $\tau_{\text {exp, flow }}$ of $1074 \mathrm{~s}$ (Fig. 2, Panel a3). Shown in Fig. 2, Panels b1-b3 is SOM being studied at $50 \%$ RH. As for the SOM in Fig. 2a, the SOM was hemispherical in geometry prior to being poked (Fig. 2, Panel b1), and the act of poking the SOM also lead to the formation of a half-torus geometry (Fig. 2, Panel b2). However, in this case the flow rate was clearly faster, and the SOM was determined to have a $\tau_{\text {exp, flow }}$ of $4.3 \mathrm{~s}$ (Fig. 2, Panel b3).

Figure 3 summarizes the RH-dependent studies. For SOM produced at a production mass concentration of $520 \mu \mathrm{g} \mathrm{m}^{-3}$ the mean $\tau_{\text {exp, flow }}$ value was a factor of 460 lower at $50 \% \mathrm{RH}$ than at $<0.5 \%$ RH (Fig. 3a). By comparison, SOM produced at a production mass concentration of $121 \mu \mathrm{g} \mathrm{m}^{-3}$ the mean

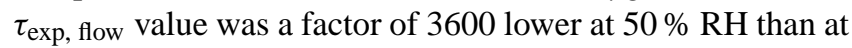
$<0.5 \%$ RH (Fig. 3b).

Based on simulations of the poke-and-flow experiments the viscosities of SOM produced at a production mass concentration of $520 \mathrm{\mu g} \mathrm{m}^{-3}$ the viscosity was between $3 \times 10^{5}$ and $2 \times 10^{7} \mathrm{Pas}$ at $<0.5 \% \mathrm{RH}$ and between $4 \times 10^{2}$ and $3 \times 10^{4} \mathrm{Pas}$ at $50 \% \mathrm{RH}$ (Fig. $3 \mathrm{c}$ ). The viscosity of SOM produced at a production mass concentration of $121 \mu \mathrm{g} \mathrm{m}^{-3}$ was determined to be between $2 \times 10^{6}$ and $6 \times 10^{7} \mathrm{Pas}$ at $<0.5 \% \mathrm{RH}$ and between $1.8 \times 10^{2}$ and $1.4 \times 10^{4} \mathrm{~Pa}$ a a $50 \%$ $\mathrm{RH}$. The results suggest the viscosity of both samples was between that of window putty and tar pitch at $<0.5 \% \mathrm{RH}$ and that of ketchup and window putty at $50 \% \mathrm{RH}$. The RHdependent results are consistent with previous work that has shown that the viscosity of SOM can depend strongly on RH (Saukko et al., 2012; Renbaum-Wolff et al., 2013; Bateman et al., 2015; Song et al., 2015; Zhang et al., 2015), with the dependence of the viscosity on RH likely being a combination of water behaving as a plasticizer and the fraction of water present in a particle increasing with RH (Koop et al., 2011).

\subsection{Effect of production mass concentration used when generating the SOM on the viscosity of SOM}

Viscosity of SOM as a function of production mass concentration used to generate SOM was studied at $30 \% \mathrm{RH}$ and $<0.5 \%$ RH. Figure 4 shows examples of SOM generated at production mass concentrations of 14000,520 , and $121 \mu \mathrm{g} \mathrm{m}^{-3}$ being poked at $<0.5 \% \mathrm{RH}$. In all cases the SOM exhibited flow, and there is a trend of increasing experimental flow time with decreasing production mass concentration.

A summary of the $\tau_{\text {exp } \text {, flow and viscosity values as a }}$ function of production mass concentration at $<0.5 \% \mathrm{RH}$ is shown in Fig. 5. Considering all the data together, as the production mass concentration decreases from 14000 to $121 \mu \mathrm{g} \mathrm{m}^{-3}$, the mean $\tau_{\text {exp }}$, flow values increase by a factor

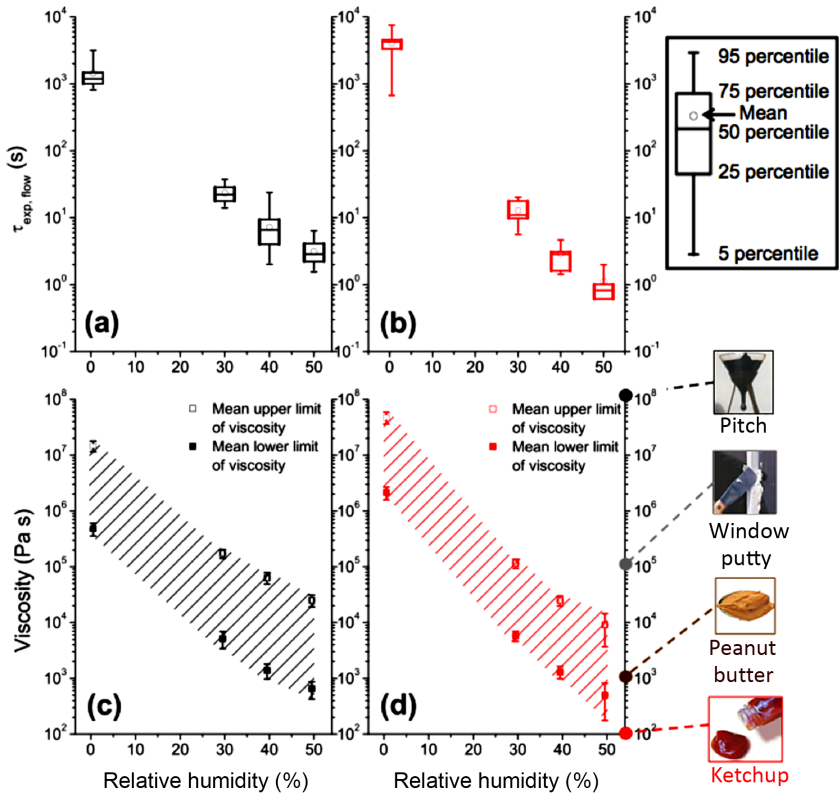

Figure 3. Summary of poke-and-flow experiments from $<0.5$ to $50 \% \mathrm{RH}$ performed on samples of the whole SOM produced at mass concentrations of $520 \mu \mathrm{g} \mathrm{m}^{-3}$ (a, c) and $121 \mu \mathrm{g} \mathrm{m}^{-3}(\mathbf{b}, \mathbf{d})$. Panels (a) and (b) show box plots of observed $\tau_{\text {exp, flow }}$ times for particles poked at different RHs. Panels (c) and (d) show the simulated lower (filled symbols) and upper (open symbols) limits of viscosity. $Y$ error bars represent $95 \%$ confidence intervals, and $x$ error bars represent the range of $\mathrm{RH}$ at which measurements were made. The shaded regions are included to guide the eye of the reader. The viscosities of common substances at room temperature have been added to (a) to provide points of reference, as per Koop et al. (2011). The image of pitch is part of an image from the pitch drop experiment (image courtesy of Wikimedia Commons, GNU Free Documentation License, University of Queensland, John Mainstone).

of 45 (Fig. 5a). Based on simulations of the poke-and-flow experiments the viscosities of the SOM samples are between $4 \times 10^{4}$ and $1.5 \times 10^{6} \mathrm{~Pa}$ s for SOM produced at a production mass concentration of $14000 \mu \mathrm{g} \mathrm{m}^{-3}$ and between $6 \times 10^{5}$ and $5 \times 10^{7} \mathrm{Pas}$ for SOM produced at a production mass concentration of $121 \mu^{-3} \mathrm{~m}^{-3}$ (Fig. 5b).

The inverse relationship between viscosity and production mass concentration is consistent with results of Shilling et al. (2009), who observed an inverse relationship between production mass concentration and the oxidation level of the resulting SOM. As previously mentioned, higher oxidation levels are linked to higher glass transition temperatures and an increased likelihood that a particle rebounds from an impactor surface.

The results for SOM produced in the flow tube (production mass concentrations of 14000 to $520 \mu^{-3} \mathrm{~m}^{-3}$ ) and produced in the chamber (production mass concentrations of 230 and $121 \mu \mathrm{g} \mathrm{m}^{-3}$ ) each exhibit the same trend: $\tau_{\text {exp } \text {, flow increases }}$ as production mass concentration decreases. However, the data are not in perfectly aligned. If the data from the flow 


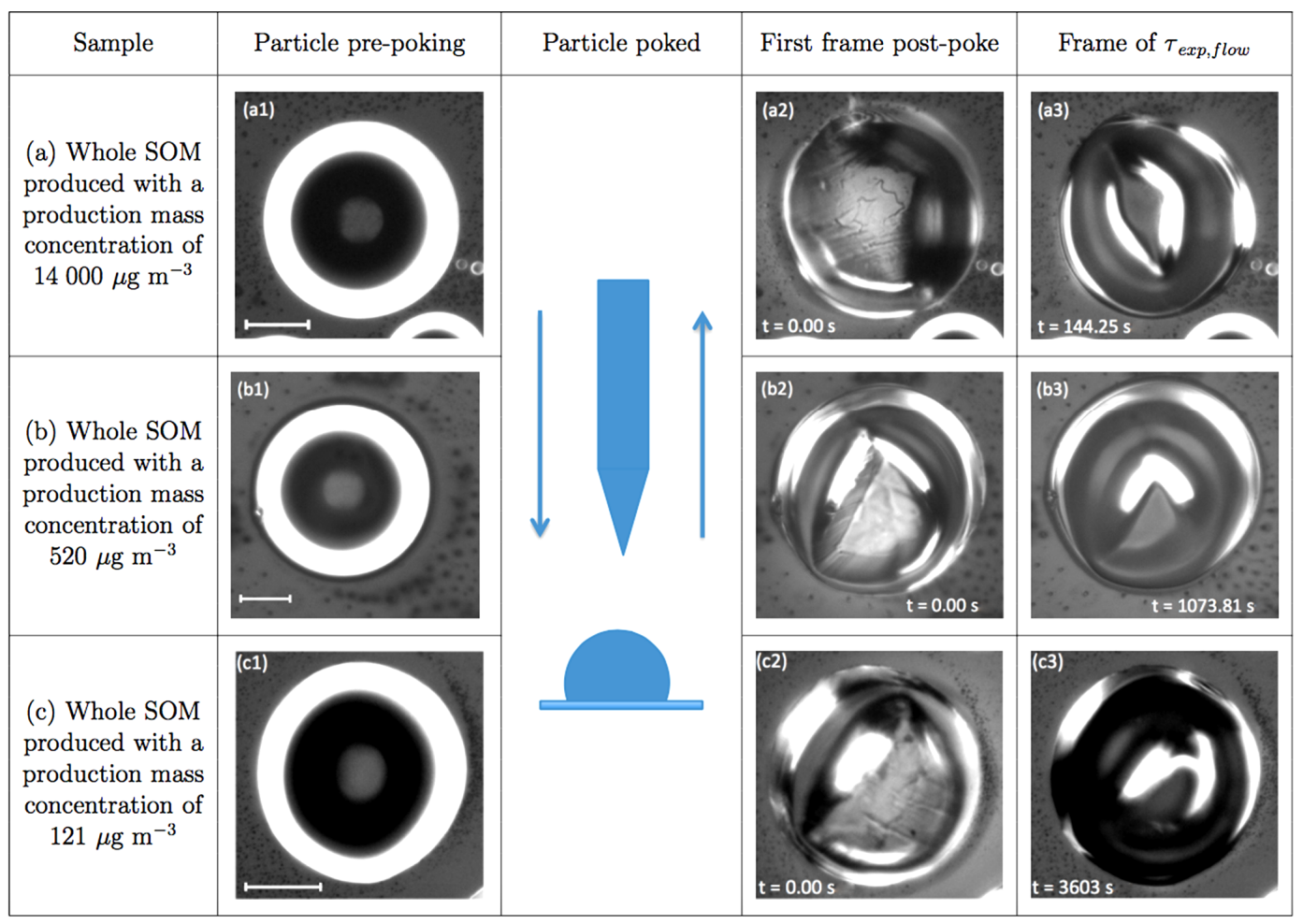

Figure 4. Optical images recorded during typical poke-and-flow experiments of particles of the whole SOM produced at production mass concentrations of (a) $14000 \mu \mathrm{g} \mathrm{m}^{-3}$, (b) $520 \mu \mathrm{g} \mathrm{m}^{-3}$, and (c) $121 \mu \mathrm{g} \mathrm{m}^{-3}$ being poked at $<0.5 \% \mathrm{RH}$. Panels (a1), (b1) and (c1) correspond to SOM prior to poking. Panels (a2), (b2) and (c2) correspond to the first frame post-poke (i.e. the first frame after the needle has been removed). Panels (a3), (b3) and (c3) correspond to images of the experimental flow time, $\tau_{\mathrm{exp}}$, flow, the point at which the diameter of the hole at the centre of the torus has decreased to $50 \%$ of its original size. Scale bar in panels (a1), (b1) and (c1): $20 \mu \mathrm{m}$.

tube are extrapolated to lower particle mass concentrations,

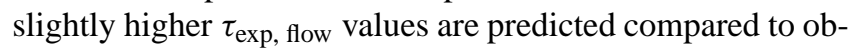
servations using samples from the chamber (roughly a factor of 2-3 higher). This difference could be due to some differences in experimental conditions. For example, the flow tube studies were carried out in the presence of an $\mathrm{OH}$ scavenger, 2-butanol, whereas no $\mathrm{OH}$ scavenger was used in the chamber studies. The presence of 2-butanol decreases the SOM yield from a given amount of precursor (Jonsson et al., 2008; Henry and Donahue, 2011). The reaction of $\mathrm{OH}$ with both $\alpha$-pinene, as well as first generation products of $\alpha$-pinene ozonolysis, can alter the chemical composition of the SOM produced (Vereecken and Peeters, 2012). Another difference in experimental conditions between the flow tube and the chamber studies was the RH at which the SOM was collected $-68 \pm 2 \%$ in flow tube studies and $91 \pm 2.5 \%$ in chamber studies. The increased humidity while SOM was being collected during the chamber studies may have resulted in a larger fraction of the more volatile components being present in the particle phase as material was collected, possibly explaining the lower than expected viscosity of the samples collected during chamber studies.

Also included in Fig. 5 are previous measurements of the viscosity of $\alpha$-pinene derived SOM measured under dry con- ditions. Zhang et al. (2015) studied material produced in the same flow tube as the material used here using a production mass concentration of $\approx 70 \mu \mathrm{g} \mathrm{m}^{-3}$, and RenbaumWolff et al. (2013) studied the water-soluble component of SOM produced at a production mass concentration of $\approx 50 \mu \mathrm{g} \mathrm{m}^{-3}$ in an environmental chamber. The results of Zhang et al. (2015) are consistent with the results obtained here. The results from Renbaum-Wolff et al. are not inconsistent with the current results due to the observed inverse relationship between viscosity and production mass concentration.

Other researchers have measured diffusion rates (Cappa and Wilson, 2011; Perraud et al., 2012; Abramson et al., 2013), or mixing times under dry conditions Robinson et al. (2013); Saleh et al. (2013) within SOM produced via the ozonolysis of $\alpha$-pinene. In the Supplement we have converted these measurements to viscosities using the StokesEinstein relationship. It should be kept in mind that the Stokes-Einstein relationship may break down for small molecules (Bones et al., 2012; Price et al., 2015) and for large molecules when the viscosity is high and near the glass transition temperature (Champion et al., 1997; Corti et al., 2008). Further discussion on the conversion of reported diffusion coefficients or mixing times to viscosities for each of 


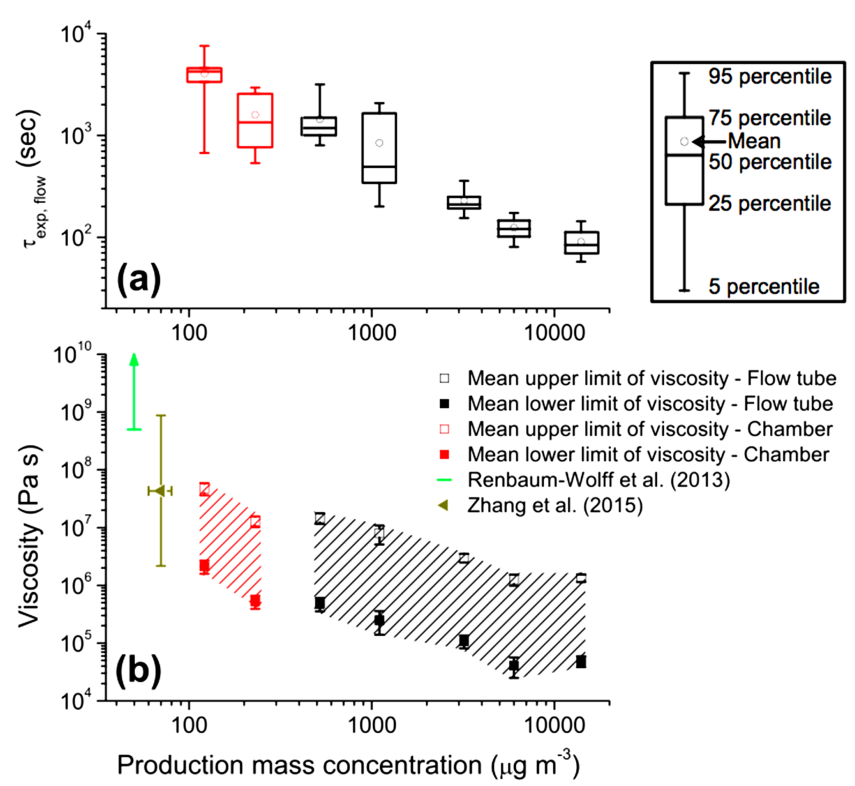

Figure 5. Summary of poke-and-flow experiments performed on samples of whole SOM at $<0.5 \%$ RH. Black symbols represent results from particles produced in a flow tube, whilst red symbols represent results from particles produced in a chamber. Panel (a) shows box plots of observed $\tau_{\text {exp, flow }}$ times at different production mass concentrations for particles poked $<0.5 \% \mathrm{RH}$. Boxes represent the 25,50 , and 75 percentiles, open circles represent median values, and whiskers represent the 5 and 95 percentiles. Panel (b) shows the simulated lower (filled squares) and upper (open squares) limit of viscosity for particles at each production mass concentration poked at $<0.5 \%$. Symbols represent mean values. The $y$ error bars represent $95 \%$ confidence intervals. The shaded regions are included to guide the eye of the reader. Also included in (b) are literature viscosities for SOM produced via the ozonolysis of $\alpha$-pinene (Renbaum-Wolff et al., 2013; Zhang et al., 2015).

these studies is given in Sect. S3. Figure S3 shows that most of these previous studies (Cappa and Wilson, 2011; Perraud et al., 2012; Saleh et al., 2013) are not inconsistent with those presented here. Some of the results are outside of the range reported here (Abramson et al., 2013; Robinson et al., 2013) suggesting factors beyond just a simple relationship between viscosity and production mass concentration are required to explain previous measurements. Differences may be due to invalid assumptions made when using the Stokes-Einstein relationship or other factors.

The effect of production mass concentration on viscosity was also studied at $30 \%$ RH (Fig. S4). At this RH, the effect of particle mass concentration was not as dramatic. For the samples produced in a flow tube, as the production mass concentration decreases from 14000 to $520 \mu \mathrm{g} \mathrm{m}^{-3}$, the mean

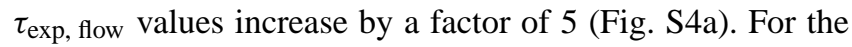
samples produced in the chamber, as the production mass concentration decreased from 230 and $121 \mu \mathrm{g} \mathrm{m}^{-3}$, the mean $\tau_{\text {exp, flow }}$ values increase by a factor of 1.5 . Similar to the ex- periments at $<0.5 \% \mathrm{RH}$, if the results from the flow tube are extrapolated to lower particle mass concentrations, they predict larger $\tau_{\text {exp, flow values than observed from the chamber }}$ studies. As mentioned above, these differences may be due to small differences in experimental conditions between the flow tube and chamber.

Based on simulation the viscosity of the SOM at $30 \%$ $\mathrm{RH}$ is between $1.0 \times 10^{3}$ and $9 \times 10^{4} \mathrm{~Pa}$ s at a production mass concentration of $14000 \mathrm{\mu g} \mathrm{m}^{-3}$ and between $1.2 \times 10^{3}$ and $1.2 \times 10^{5} \mathrm{Pas}$ at a production mass concentration of $121 \mu \mathrm{g} \mathrm{m}^{-3}$ (Fig. S4b). The smaller dependence of viscosity on production mass concentration at $30 \% \mathrm{RH}$ compared to $<0.5 \% \mathrm{RH}$ can be explained by the dependence of the viscosity on the water content of the SOM. Under dry conditions the measured viscosity is due only to the viscosity of the SOM. However, as RH is increased the SOM uptakes water, and the viscosity of the different SOM samples become increasingly dependent on the viscosity of water and converge, finally approaching the viscosity of water, $\approx 10^{-3} \mathrm{Pas}$, at $100 \% \mathrm{RH}$.

Also included in Fig. S4b are viscosities of $\alpha$-pinenederived SOM measured at 30\% RH by Zhang et al. (2015) and Renbaum-Wolff et al. (2013). As mentioned above Zhang et al. (2015) studied material produced in the same flow tube as the material used here, and Renbaum-Wolff et al. (2013) studied the water-soluble component of SOM produced in an environmental chamber. One possible explanation of the results shown in Fig. S4b is a very strong dependence of viscosity on production mass concentration in the range of 50 and $121 \mathrm{\mu g} \mathrm{m}^{-3}$. To determine if a strong dependence of viscosity in the range of 50 and $121 \mu^{-3} \mathrm{~m}^{-3}$ shown in Fig. S4b exists or due to other factors, additional studies are needed. More importantly, additional studies are needed to determine if the viscosity of the water-soluble component of SOM is the same as the viscosity of the whole SOM (water-soluble and water-insoluble components) produced at production mass concentrations around $50 \mu \mathrm{g} \mathrm{m}^{-3}$. In addition, further comparison studies using the technique introduced by Zhang et al. (2015) and the poke-and-flow technique used here would be beneficial. Finally, the studies here are carried out at production mass concentrations greater than those found under ambient conditions (Hallquist et al., 2009; Slowik et al., 2010). Studies carried out using material produced under ambient conditions would provide further useful information. The inverse relationship between viscosity and production mass concentration suggests the results determined here likely represent a lower limit of viscosity for SOM produced by the ozonolysis of $\alpha$-pinene in the atmosphere.

\subsection{Effect of the water-insoluble component on the viscosity of SOM}

To better understand the difference between the viscosity of water-soluble SOM and SOM containing both the water- 


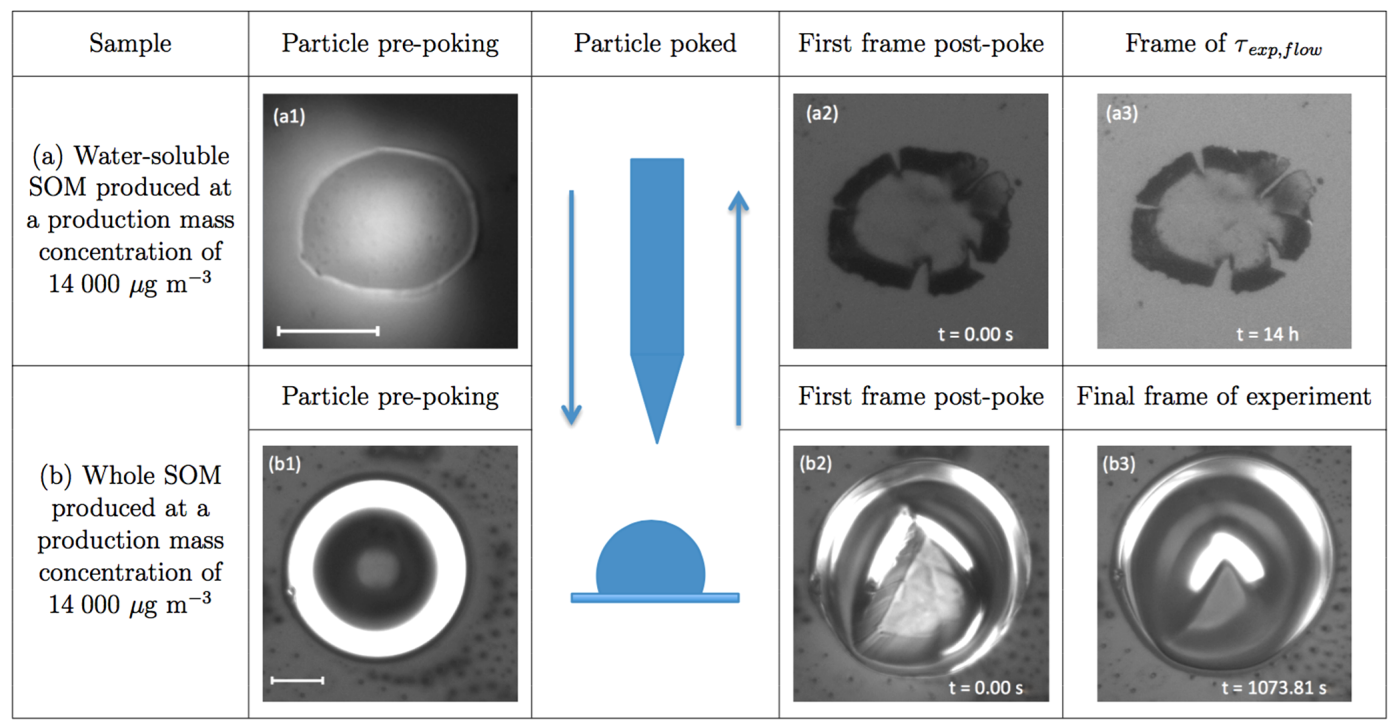

Figure 6. Optical images recorded during poke-and-flow experiments using particles consisting of (a) the water-soluble component of the SOM and (b) the whole SOM (i.e., both the water-soluble and the water-insoluble components). In both experiments the SOM was produced using a mass concentration of $14000 \mu \mathrm{g} \mathrm{m}^{-3}$ and was poked at $<0.5 \% \mathrm{RH}$. Panels (a1) and (b1) correspond to the SOM prior to being poked. The brightness in panel (a1) is due to reflection of the source light by the needle positioned just above the particle. Panels (a2) and (b2) correspond to the first frame post-poke (i.e. the first frame after the needle has been removed). The particle comprised of the watersoluble component of SOM exhibited cracking behaviour and, as shown in panel (a3), no change in the size or shape of the cracks can be observed $14 \mathrm{~h}$ after the particle has been poked. The particle comprised of whole SOM exhibited flow, and panel (b3) corresponds to an image

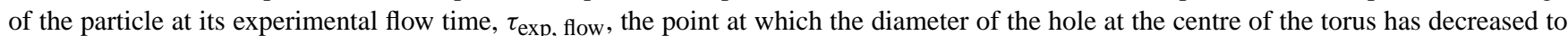
$50 \%$ of its original size. Scale bar in panels (a1) and (b1): $20 \mu \mathrm{m}$.

soluble and water-insoluble components, additional measurements were carried out using just the water-soluble component of SOM generated by the ozonolysis of $\alpha$-pinene at a production mass concentration of $14000 \mu \mathrm{g} \mathrm{m}^{-3}$. Particles were generated using the flow tube as discussed in Sect. 2.1, and particles from the outlet of the flow tube were collected on a Teflon filter. After collection, SOM was extracted from the Teflon filter by placing it in a clean glass jar and immersing the filter in $10 \mathrm{~mL}$ of Millipore $(18.2 \mathrm{M} \Omega \mathrm{cm})$ water. The jar was shaken for $1.5 \mathrm{~h}$, with the filter being flipped over half way through, after which the filter was removed from the jar, resulting in a solution of the water-soluble component of the SOM. The solution was then nebulized and sprayed onto a hydrophobic glass substrate, producing super-micron sized particles. The particles were then studied using the poke-andflow technique and their viscosities determined using simulations of fluid flow as described in Sects. 2.3, 2.4, and S4.

Shown in Fig. 6 are images of a particle comprised of the water-soluble fraction of SOM (Fig. 6a) and a particle comprised of the whole SOM, both the water-soluble and water-insoluble fractions (Fig. 6b). Both were produced at a production mass concentration of $14000 \mu \mathrm{g} \mathrm{m}^{-3}$ and studied at $<0.5 \% \mathrm{RH}$. Although the production of both the watersoluble SOM and the whole SOM took place using equivalent flow tube conditions, the images of the SOM during the poke-and-flow experiments were clearly different, with

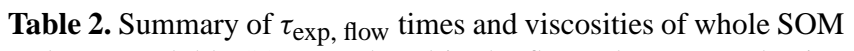
and water-soluble SOM produced in the flow tube at a production mass concentration of $14000 \mathrm{~g} \mathrm{~m}^{-3}$ and studied at $<0.5 \% \mathrm{RH}$.

\begin{tabular}{lll}
\hline & $\tau_{\text {exp, flow }}{ }^{\mathrm{a}}$ & ${\text { Viscosity }(\mathrm{Pa} \mathrm{s})^{\mathrm{b}}}$ \\
\hline Water-soluble SOM & $>4.3 \times 10^{4}$ & $>4.8 \times 10^{8}$ \\
Whole SOM & $90(57,144)$ & $3.8 \times 10^{4}-1.5 \times 10^{6}$ \\
\hline
\end{tabular}

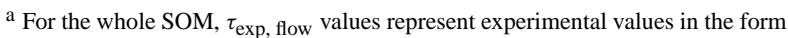
"mean (5th percentile, 95 th percentile)". For the water-soluble SOM, the lower

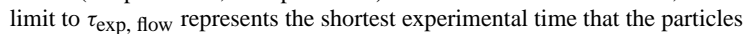
were observed. ${ }^{b}$ For whole SOM, the lower limit of viscosity represents the lower $95 \%$ confidence interval of the lower limit of viscosity, whilst the upper limit of viscosity represents the upper $95 \%$ confidence interval of the upper limit of viscosity. For water-soluble SOM the lower limit of viscosity was calculated for the particles observed over the shortest experimental time.

the water-soluble SOM cracking and showing no observable flow over the course of $14 \mathrm{~h}$ (Fig. $6 \mathrm{a} 2$ and a3), whilst the whole SOM exhibited flow, with a $\tau_{\text {exp flow }}$ of $1074 \mathrm{~s}$ (Fig. 6b2 and b3).

Table 2 summarizes experimental results at $<0.5 \% \mathrm{RH}$ for both the water-soluble SOM and the whole SOM produced at a production mass concentration of $14000 \mu \mathrm{g} \mathrm{m}^{-3}$. The $\tau_{\text {exp, flow }}$ and viscosity of the water-soluble component were both at least a factor of 300 greater than the $\tau_{\text {exp } \text {, flow }}$ and viscosity of the whole SOM. 
The difference in viscosity between the whole SOM and the water-soluble SOM may arise from differences in the extent of oxidation of the SOM. Water-soluble SOM is assumed to be composed of the more oxidized components of the whole SOM and literature suggests that higher oxidation is related to a warmer glass transition temperature (Koop et al., 2011; Berkemeier et al., 2014; Dette et al., 2014), implying that viscosity increases with oxidation level.

The results for Table 2 correspond to a high production mass concentration. At lower SOM particle concentrations such as concentrations used by Renbaum-Wolff et al. (2013) the difference between water-soluble SOM and whole SOM is likely smaller, since as the production mass concentration decreases, the extent of oxidation in the particle phase is expected to increase and hence the amount of water insoluble material in the particle phase should decrease. In addition, literature suggests that the SOM formed from the ozonolysis of $\alpha$-pinene is largely composed of water-soluble organic compounds (Hall and Johnston, 2011) produced using a production mass concentration of $<500 \mu \mathrm{g} \mathrm{m}^{-3}$. Further, mass spectral analysis has revealed little difference in the chemical composition of SOM produced via the ozonolysis of $\alpha$ pinene and extracted using either water or a methanol: water solution (Heaton et al., 2007), and cloud condensation measurements suggest SOM generated via the ozonolysis of $\alpha$ pinene is not limited by solubility of the organic material in water (King et al., 2009) for SOM produced at production mass concentrations of $<100 \mu \mathrm{g} \mathrm{m}^{-3}$. Based on these arguments the results shown in Table 2 should be considered as an upper limit to the difference between the viscosity of water-soluble SOM and whole SOM produced using production mass concentrations lower than $14000 \mu \mathrm{g} \mathrm{m}^{-3}$.

Hosny et al. (2016) recently studied the viscosity of SOM generated from the ozonolysis of myrcene and observed a difference in viscosity between the water soluble fraction and the whole SOM samples. In their case similar viscosities were observed at the lowest RH values studied $(<40 \%)$ but the whole SOM samples had a higher viscosity than the water soluble fraction at the highest $\mathrm{RH}$ values studied $(>70 \%)$. The reason for the difference between the results here and those of Hosny et al. (2016) is not clear.

\section{Summary}

The effect of various experimental parameters on the viscosity of SOM derived via the ozonolysis of $\alpha$-pinene have been studied. First, the effect of relative humidity on the viscosity of the whole SOM was studied. For each sample studied the $\tau_{\text {exp, flow }}$ values were larger and the simulated viscosities higher as the RH was decreased from 50 to $<0.5 \%$ (Figs. 2 and 3). Specifically, for SOM produced at a production mass

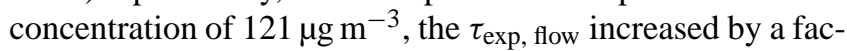
tor of 3600 as the relative humidity (RH) decreased from 50 to $<0.5 \%$ RH. Based on simulations, the viscosities of the particles were between $3 \times 10^{2}$ and $9 \times 10^{3} \mathrm{~Pa}$ at $50 \% \mathrm{RH}$ and between $6 \times 10^{5}$ and $5 \times 10^{7} \mathrm{Pas}$ at $<0.5 \% \mathrm{RH}$.

Second, the effect on viscosity of the production mass concentration used during the production of SOM was investigated at 30 and $<0.5 \% \mathrm{RH}$. The measurements provide evidence of an inverse relationship between production mass concentration in the reaction vessel and viscosity of the SOM material (Figs. 4 and 5). The effect was most prominent at $<0.5 \% \mathrm{RH}$ where $\tau_{\text {exp, flow increased by }}$ a factor of 45 as the particle mass concentration decreased from 14000 to $121 \mathrm{\mu g} \mathrm{m}^{-3}$. From simulations of the pokeand-flow experiments, the viscosity of the SOM produced at a production mass concentration of $14000 \mathrm{\mu g} \mathrm{m}^{-3}$ are between $4 \times 10^{4}$ and $1.5 \times 10^{6} \mathrm{Pas}$ and the viscosity of SOM produced at a production mass concentration of $121 \mu \mathrm{g} \mathrm{m}^{-3}$ are between $6 \times 10^{5}$ and $5 \times 10^{7} \mathrm{Pas}$ at $<0.5 \% \mathrm{RH}$ (Fig. 5). These studies were carried out at production mass concentrations greater than those found under ambient conditions. The inverse relationship between viscosity and production mass concentration suggests the results determined here likely represent a lower limit of viscosity for SOM produced by the ozonolysis of $\alpha$-pinene in the atmosphere.

We also observed that $\tau_{\text {exp, flow }}$ and viscosity of the water-soluble component of SOM was at least a factor of 300 greater than the $\tau_{\exp \text {, flow }}$ and viscosity of the whole SOM when using a production mass concentration of $14000 \mu \mathrm{g} \mathrm{m}^{-3}$. This result should be considered as an upper limit to the difference between the viscosity of water-soluble SOM and whole SOM produced at production mass concentrations lower than $14000 \mu \mathrm{g} \mathrm{m}^{-3}$.

Overall the results suggest that the $\mathrm{RH}$ at which the viscosity was determined and the mass concentration at which the SOM was produced should be considered when laboratory experiments are being compared or when used to infer viscosities of atmospheric particles.

\section{The Supplement related to this article is available online at doi:10.5194/acp-16-6027-2016-supplement.}

Acknowledgements. We thank the Natural Science and Engineering Research Council of Canada for funding. Support from the US National Science Foundation and the US Department of Energy is also acknowledged.

Edited by: T. Koop

\section{References}

Abramson, E., Imre, D., Beránek, J., Wilson, J., and Zelenyuk, A.: Experimental determination of chemical diffusion within secondary organic aerosol particles, Phys. Chem. Chem. Phys., 15, 2983-2991, doi:10.1039/c2cp44013j, 2013. 
Adler, G., Koop, T., Haspel, C., Taraniuk, I., Moise, T., Koren, I., Heiblum, R. H., and Rudich, Y.: Formation of highly porous aerosol particles by atmospheric freeze-drying in ice clouds, P. Natl. Acad. Sci. USA, 110, 20414-20419, doi:10.1073/pnas.1317209110, 2013.

Andreae, M. O. and Crutzen, P.: Atmospheric aerosols: biogeochemical sources and role in atmospheric chemistry, Science, 276, 1052-1058, doi:10.1126/science.276.5315.1052, 1997.

Baltensperger, U., Dommen, J., Alfarra, M. R., Duplissy, J., Gaeggeler, K., Metzger, A., Facchini, M. C., Decesari, S., Finessi, E., Reinnig, C., Schott, M., Warnke, J., Hoffmann, T., Klatzer, B., Puxbaum, H., Geiser, M., Savi, M., Lang, D., Kalberer, M., and Geiser, T.: Combined determination of the chemical composition and of health effects of secondary organic aerosols: The POLYSOA project, J. Aerosol. Med. Pulm. D., 21, 145-154, doi:10.1089/jamp.2007.0655, 2008.

Bateman, A. P., Bertram, A. K., and Martin, S. T.: Hygroscopic influence on the semisolid-to-liquid transition of secondary organic materials, J. Phys. Chem. A, 119, 4386-4395, doi:10.1021/jp508521c, 2015.

Baustian, K. J., Wise, M. E., Jensen, E. J., Schill, G. P., Freedman, M. A., and Tolbert, M. A.: State transformations and ice nucleation in amorphous (semi-)solid organic aerosol, Atmos. Chem. Phys., 13, 5615-5628, doi:10.5194/acp-13-5615-2013, 2013.

Berkemeier, T., Shiraiwa, M., Pöschl, U., and Koop, T.: Competition between water uptake and ice nucleation by glassy organic aerosol particles, Atmos. Chem. Phys., 14, 12513-12531, doi:10.5194/acp-14-12513-2014, 2014.

Bodsworth, A., Zobrist, B., and Bertram, A. K.: Inhibition of efflorescence in mixed organic-inorganic particles at temperatures less than 250 K, Phys. Chem. Chem. Phys., 12, 12259-12266, doi:10.1039/c0cp00572j, 2010.

Bones, D. L., Reid, J. P., Lienhard, D. M., and Krieger, U. K.: Comparing the mechanism of water condensation and evaporation in glassy aerosol, P. Natl. Acad. Sci. USA, 109, 11613-11618, doi:10.1073/pnas.1200691109, 2012.

Booth, A. M., Murphy, B., Riipinen, I., Percival, C. J., and Topping, D. O.: Connecting bulk viscosity measurements to kinetic limitations on attaining equilibrium for a model aerosol composition, Environ. Sci. Technol., 48, 9298-9305, doi:10.1021/es501705c, 2014.

Cappa, C. D. and Wilson, K. R.: Evolution of organic aerosol mass spectra upon heating: implications for OA phase and partitioning behavior, Atmos. Chem. Phys., 11, 1895-1911, doi:10.5194/acp11-1895-2011, 2011.

Champion, D., Hervet, H., Blond, G., Le Meste, M., and Simatos, D.: Translational diffusion in sucrose solutions in the vicinity of their glass transition temperature, J. Phys. Chem. B, 101, 1067410679, 1997.

Choularton, T. W., Bower, K. N., Weingartner, E., Crawford, I., Coe, H., Gallagher, M. W., Flynn, M., Crosier, J., Connolly, P., Targino, A., Alfarra, M. R., Baltensperger, U., Sjogren, S., Verheggen, B., Cozic, J., and Gysel, M.: The influence of small aerosol particles on the properties of water and ice clouds, Faraday Discuss., 137, 205-222, doi:10.1039/b702722m, 2007.

Corti, H. R., Frank, G. A., and Marconi, M. C.: Diffusion-viscosity decoupling in supercooled aqueous trehalose solutions, J. Phys. Chem. B, 112, 12899-12906, doi:10.1021/jp802806p, 2008.
Dette, H. P., Qi, M., Schröder, D. C., Godt, A., and Koop, T.: Glass-forming properties of 3-methylbutane-1,2,3-tricarboxylic acid and its mixtures with water and pinonic acid, J. Phys. Chem. A, 118, 7024-7033, doi:10.1021/jp505910w, 2014.

Ervens, B., Turpin, B. J., and Weber, R. J.: Secondary organic aerosol formation in cloud droplets and aqueous particles (aqSOA): a review of laboratory, field and model studies, Atmos. Chem. Phys., 11, 11069-11102, doi:10.5194/acp-1111069-2011, 2011.

Grayson, J. W., Song, M., Sellier, M., and Bertram, A. K.: Validation of the poke-flow technique combined with simulations of fluid flow for determining viscosities in samples with small volumes and high viscosities, Atmos. Meas. Tech., 8, 2463-2472, doi:10.5194/amt-8-2463-2015, 2015.

Hall IV, W. A. and Johnston, M. V.: Oligomer content of $\alpha$-pinene secondary organic aerosol, Aerosol Sci. Technol., 45, 37-45, doi:10.1080/02786826.2010.517580, 2011.

Hallquist, M., Wenger, J. C., Baltensperger, U., Rudich, Y., Simpson, D., Claeys, M., Dommen, J., Donahue, N. M., George, C., Goldstein, A. H., Hamilton, J. F., Herrmann, H., Hoffmann, T., Iinuma, Y., Jang, M., Jenkin, M. E., Jimenez, J. L., Kiendler-Scharr, A., Maenhaut, W., McFiggans, G., Mentel, Th. F., Monod, A., Prévôt, A. S. H., Seinfeld, J. H., Surratt, J. D., Szmigielski, R., and Wildt, J.: The formation, properties and impact of secondary organic aerosol: current and emerging issues, Atmos. Chem. Phys., 9, 5155-5236, doi:10.5194/acp-9-51552009, 2009.

Hamed, A., Korhonen, H., Sihto, S.-L., Joutsensaari, J., Järvinen, H., Petäjä, T., Arnold, F., Nieminen, T., Kulmala, M., Smith, J. N., Lehtinen, K. E. J., and Laaksonen, A.: The role of relative humidity in continental new particle formation, J. Geophys. Res., 116, D03202, doi:10.1029/2010JD014186, 2011.

Hawkins, L. N., Baril, M. J., Sedehi, N., M, G. M., De Haan, D. O., Schill, G. P., and Tolbert, M. A.: Formation of semisolid, oligomerized aqueous SOA: lab simulations of cloud processing, Environ. Sci. Technol., 48, 2273-2280, doi:10.1021/es4049626, 2014.

Heaton, K. J., Dreyfus, M. A., Wang, S., and Johnston, M. V.: Oligomers in the early stage of biogenic secondary organic aerosol formation and growth, Environ. Sci. Technol., 41, 61296136, doi:10.1021/es070314n, 2007.

Henry, K. M. and Donahue, N. M.: Effect of the OH radical scavenger hydrogen peroxide on secondary organic aerosol formation from $\alpha$-pinene ozonolysis, Aerosol Sci. Technol., 45, 696-700, doi:10.1080/02786826.2011.552926, 2011.

Hosny, N. A., Fitzgerald, C., Tong, C., Kalberer, M., Kuimova, M. K., and Pope, F. D.: Fluorescent lifetime imaging of atmospheric aerosols: a direct probe of aerosol viscosity, Faraday Discuss., 165, 343-356, doi:10.1039/c3fd00041a, 2013.

Hosny, N. A., Fitzgerald, C., Vyšniauskas, A., Athanasiadis, A., Berkemeier, T., Uygur, N., Pöschl, U., Shiraiwa, M., Kalberer, M., Pope, F. D., and Kuimova, M. K.: Direct imaging of changes in aerosol particle viscosity upon hydration and chemical aging, Chem. Sci., 7, 1357-1367, doi:10.1039/C5SC02959G, 2016.

Houle, F. A., Hinsberg, W. D., and Wilson, K. R.: Oxidation of a model alkane aerosol by $\mathrm{OH}$ radical: the emergent nature of reactive uptake, Phys. Chem. Chem. Phys., 17, 4412-4423, doi:10.1039/c4cp05093b, 2015. 
Iinuma, Y., Böge, O., Kahnt, A., and Herrmann, H.: Laboratory chamber studies on the formation of organosulfates from reactive uptake of monoterpene oxides, Phys. Chem. Chem. Phys., 11, 7985-7997, doi:10.1039/b904025k, 2009.

Jonsson, Å. M., Hallquist, M., and Ljungström, E.: Influence of $\mathrm{OH}$ scavenger on the water effect on secondary organic aerosol formation from ozonolysis of limonene, $\Delta 3$-carene, and $\alpha$-pinene, Environ. Sci. Technol., 42, 5938-5944, doi:10.1021/es702508y, 2008.

Kidd, C., Perraud, V., Wingen, L. M., and Finlayson-Pitts, B. J.: Integrating phase and composition of secondary organic aerosol from the ozonolysis of $\alpha$-pinene, P. Natl. Acad. Sci. USA, 111, 7552-7557, doi:10.1073/pnas.1322558111, 2014.

King, S. M., Rosenoern, T., Shilling, J. E., Chen, Q., and Martin, S. T.: Increased cloud activation potential of secondary organic aerosol for atmospheric mass loadings, Atmos. Chem. Phys., 9, 2959-2971, doi:10.5194/acp-9-2959-2009, 2009.

Knopf, D. A. and Rigg, Y. J.: Homogeneous ice nucleation from aqueous inorganic/organic particles representative of biomass burning: water activity, freezing temperatures, nucleation rates, J. Phys. Chem. A, 115, 762-773, 2011.

Koop, T., Bookhold, J., Shiraiwa, M., and Pöschl, U.: Glass transition and phase state of organic compounds: dependency on molecular properties and implications for secondary organic aerosols in the atmosphere, Phys. Chem. Chem. Phys., 13, 19238-19255, doi:10.1039/c1cp22617g, 2011.

Kuwata, M. and Martin, S. T.: Phase of atmospheric secondary organic material affects its reactivity, P. Natl. Acad. Sci. USA, 109, 17354-17359, doi:10.1073/pnas.1209071109, 2012.

Ladino, L. A., Zhou, S., Yakobi Hancock, J. D., Aljawhary, D., and Abbatt, J. P. D.: Factors controlling the ice nucleating abilities of $\alpha$-pinene SOA particles, J. Geophys. Res.-Atmos., 119, 90419051, doi:10.1002/2014JD021578, 2014.

Lignell, H., Hinks, M. L., and Nizkorodov, S. A.: Exploring matrix effects on photochemistry of organic aerosols, P. Natl. Acad. Sci. USA, 111, 13780-13785, doi:10.1073/pnas.1322106111, 2014.

Loza, C. L., Coggon, M. M., Nguyen, T. B., Zuend, A., Flagan, R. C., and Seinfeld, J. H.: On the mixing and evaporation of secondary organic aerosol components, Environ. Sci. Technol., 47, 6173-6180, doi:10.1021/es400979k, 2013.

Lu, J. W., Rickards, A. M. J., Walker, J. S., Knox, K. J., Miles, R. E. H., Reid, J. P., and Signorell, R.: Timescales of water transport in viscous aerosol: measurements on sub-micron particles and dependence on conditioning history, Phys. Chem. Chem. Phys., 16, 9819-9830, doi:10.1039/c3cp54233e, 2014.

Murray, B. J. and Bertram, A. K.: Inhibition of solute crystallisation in aqueous $\mathrm{H}^{+}-\mathrm{NH}_{4}^{+}-\mathrm{SO}_{4}^{2}-\mathrm{H}_{2} \mathrm{O}$ droplets, Phys. Chem. Chem. Phys., 10, 3287-3301, doi:10.1039/b802216j, 2008.

Murray, B. J., Wilson, T. W., Dobbie, S., Cui, Z., Al-Jumur, S. M. R. K., Möhler, O., Schnaiter, M., Wagner, R., Benz, S., Niemand, M., Saathoff, H., Ebert, V., Wagner, S., and Kärcher, B.: Heterogeneous nucleation of ice particles on glassy aerosols under cirrus conditions, Nat. Geosci., 3, 233-237, doi:10.1038/ngeo817, 2010.

Murray, B. J., Haddrell, A. E., Peppe, S., Davies, J. F., Reid, J. P., O'Sullivan, D., Price, H. C., Kumar, R., Saunders, R. W., Plane, J. M. C., Umo, N. S., and Wilson, T. W.: Glass formation and unusual hygroscopic growth of iodic acid solution droplets with relevance for iodine mediated particle formation in the marine boundary layer, Atmos. Chem. Phys., 12, 8575-8587, doi:10.5194/acp-12-8575-2012, 2012.

O’Brien, R. E., Neu, A., Epstein, S. A., MacMillan, A. C., Wang, B., Kelly, S. T., Nizkorodov, S. A., Laskin, A., Moffet, R. C., and Gilles, M. K.: Physical properties of ambient and laboratorygenerated secondary organic aerosol, Geophys. Res. Lett., 41, 4347-4353, doi:10.1002/2014GL060219, 2014.

Pajunoja, A., Malila, J., Hao, L., Joutsensaari, J., Lehtinen, K. E. J., and Virtanen, A.: Estimating the viscosity range of SOA particles based on their coalescence time, Aerosol Sci. Technol., 48, i-iv, doi:10.1080/02786826.2013.870325, 2014.

Perraud, V., Bruns, E. A., Ezell, M. J., Johnson, S. N., Yu, Y., Alexander, M. L., Zelenyuk, A., Imre, D., Chang, W. L., Dabdub, D., Pankow, J. F., and Finlayson-Pitts, B. J.: Nonequilibrium atmospheric secondary organic aerosol formation and growth, P. Natl. Acad. Sci. USA, 109, 2836-2841, doi:10.1073/pnas.1119909109, 2012.

Price, H. C., Murray, B. J., Mattsson, J., O’Sullivan, D., Wilson, T. W., Baustian, K. J., and Benning, L. G.: Quantifying water diffusion in high-viscosity and glassy aqueous solutions using a Raman isotope tracer method, Atmos. Chem. Phys., 14, 38173830, doi:10.5194/acp-14-3817-2014, 2014.

Price, H. C., Mattsson, J., Zhang, Y., Bertram, A. K., Davies, J. F., Grayson, J. W., Martin, S. T., O’Sullivan, D., Reid, J. P., Rickards, A. M. J., and Murray, B. J.: Water diffusion in atmospherically relevant $\alpha$-pinene secondary organic material, Chem. Sci., 6, 4876-4883, doi:10.1039/C5SC00685F, 2015.

Reinhardt, A., Emmenegger, C., Gerrits, B., Panse, C., Dommen, J., Baltensperger, U., Zenobi, R., and Kalberer, M.: Ultrahigh mass resolution and accurate mass measurements as a tool to characterize oligomers in secondary organic aerosols, Anal. Chem., 79, 4074-4082, doi:10.1021/ac062425v, 2007.

Renbaum-Wolff, L., Grayson, J. W., Bateman, A. P., Kuwata, M., Sellier, M., Murray, B. J., Shilling, J. E., Martin, S. T., and Bertram, A. K.: Viscosity of $\alpha$-pinene secondary organic material and implications for particle growth and reactivity, P. Natl. Acad. Sci. USA, 110, 8014-8019, doi:10.1073/pnas.1219548110, 2013.

Riipinen, I., Pierce, J. R., Yli-Juuti, T., Nieminen, T., Häkkinen, S., Ehn, M., Junninen, H., Lehtipalo, K., Petäjä, T., Slowik, J., Chang, R., Shantz, N. C., Abbatt, J., Leaitch, W. R., Kerminen, V.-M., Worsnop, D. R., Pandis, S. N., Donahue, N. M., and Kulmala, M.: Organic condensation: a vital link connecting aerosol formation to cloud condensation nuclei $(\mathrm{CCN})$ concentrations, Atmos. Chem. Phys., 11, 3865-3878, doi:10.5194/acp-11-38652011, 2011.

Robinson, C. B., Schill, G. P., and Tolbert, M. A.: Optical growth of highly viscous organic/sulfate particles, J. Atmos. Chem., 71, 145-156, doi:10.1007/s10874-014-9287-8, 2014.

Robinson, E. S., Saleh, R., and Donahue, N. M.: Organic aerosol mixing observed by single-particle mass spectrometry, J. Phys. Chem. A, 117, 13935-13945, doi:10.1021/jp405789t, 2013.

Saggin, R. and Coupland, J. N.: Rheology of xanthan/sucrose mixtures at ultrasonic frequencies, J. Food Eng., 65, 49-53, doi:10.1016/j.jfoodeng.2003.12.002, 2004.

Saleh, R., Donahue, N. M., and Robinson, A. L.: Time scales for gas-particle partitioning equilibration of secondary organic aerosol formed from alpha-pinene ozonolysis, Environ. Sci. Technol., 47, 5588-5594, doi:10.1021/es400078d, 2013. 
Saukko, E., Lambe, A. T., Massoli, P., Koop, T., Wright, J. P., Croasdale, D. R., Pedernera, D. A., Onasch, T. B., Laaksonen, A., Davidovits, P., Worsnop, D. R., and Virtanen, A.: Humiditydependent phase state of SOA particles from biogenic and anthropogenic precursors, Atmos. Chem. Phys., 12, 7517-7529, doi:10.5194/acp-12-7517-2012, 2012.

Schill, G. P., De Haan, D. O., and Tolbert, M. A.: Heterogeneous ice nucleation on simulated secondary organic aerosol, Environ. Sci. Technol., 48, 1675-1682, doi:10.1021/es4046428, 2014.

Shilling, J. E., Chen, Q., King, S. M., Rosenoern, T., Kroll, J. H., Worsnop, D. R., DeCarlo, P. F., Aiken, A. C., Sueper, D., Jimenez, J. L., and Martin, S. T.: Loading-dependent elemental composition of $\alpha$-pinene SOA particles, Atmos. Chem. Phys., 9, 771-782, doi:10.5194/acp-9-771-2009, 2009.

Shiraiwa, M. and Seinfeld, J. H.: Equilibration timescale of atmospheric secondary organic aerosol partitioning, Geophys. Res. Lett., 39, L24801, doi:10.1029/2012GL054008, 2012.

Shiraiwa, M., Ammann, M., Koop, T., and Pöschl, U.: Gas uptake and chemical aging of semisolid organic aerosol particles, P. Natl. Acad. Sci. USA, 108, 11003-11008, doi:10.1073/pnas.1103045108, 2011.

Shiraiwa, M., Zuend, A., Bertram, A. K., and Seinfeld, J. H.: Gasparticle partitioning of atmospheric aerosols: interplay of physical state, non-ideal mixing and morphology, Phys. Chem. Chem. Phys., 15, 11441-11453, doi:10.1039/c3cp51595h, 2013.

Shrestha, M., Zhang, Y., Ebben, C. J., Martin, S. T., and Geiger, F. M.: Vibrational sum frequency generation spectroscopy of secondary organic material produced by condensational growth from $\alpha$-pinene ozonolysis, J. Phys. Chem. A, 117, 8427-8436, doi:10.1021/jp405065d, 2013.

Slowik, J. G., Stroud, C., Bottenheim, J. W., Brickell, P. C., Chang, R. Y.-W., Liggio, J., Makar, P. A., Martin, R. V., Moran, M. D., Shantz, N. C., Sjostedt, S. J., van Donkelaar, A., Vlasenko, A., Wiebe, H. A., Xia, A. G., Zhang, J., Leaitch, W. R., and Abbatt, J. P. D.: Characterization of a large biogenic secondary organic aerosol event from eastern Canadian forests, Atmos. Chem. Phys., 10, 2825-2845, doi:10.5194/acp-10-2825-2010, 2010.

Solomon, S., Qin, D., Manning, M., Alley, R. B., Bernsten, T., Bindoff, N. L., Chen, Z., Chidthaisong, A., Gregory, J. M., GC, H., Heimann, M., Hewiston, B., Hoskins, B. J., Joos, F., Jouzel, J., Kattsov, V., Lohmann, U., Matsuno, T., Molina, M., Nicholls, N., Overpeck, J., Raga, G., Ramaswamy, V., Ren, J., Rusticucci, M., Somerville, R., Stocker, T. F., Whetton, P., Wood, R. A., and Wratt, D.: Technical Summary, in: Climate Change 2007: The Physical Science Basis, Contribution of Working Group I to the Fourth Assessment Report of the Intergovernmental Panel on Climate Change, edited by: Solomon, S., Qin, D., Manning, M., Chen, Z., Marquis, M., Averyt, K. B., Tignor, M., and Miller, H. L., Cambridge University Press, Cambridge, United Kingdom and New York, NY, USA, 2007.

Song, M., Marcolli, C., Krieger, U. K., Zuend, A., and Peter, T.: Liquid-liquid phase separation and morphology of internally mixed dicarboxylic acids/ammonium sulfate/water particles, Atmos. Chem. Phys., 12, 2691-2712, doi:10.5194/acp-12-26912012, 2012.

Song, M., Liu, P. F., Hanna, S. J., Li, Y. J., Martin, S. T., and Bertram, A. K.: Relative humidity-dependent viscosities of isoprene-derived secondary organic material and atmospheric implications for isoprene-dominant forests, Atmos. Chem. Phys., 15, 5145-5159, doi:10.5194/acp-15-5145-2015, 2015.

Tong, H.-J., Reid, J. P., Bones, D. L., Luo, B. P., and Krieger, U. K.: Measurements of the timescales for the mass transfer of water in glassy aerosol at low relative humidity and ambient temperature, Atmos. Chem. Phys., 11, 4739-4754, doi:10.5194/acp-11-47392011, 2011.

Vaden, T. D., Imre, D., Beránek, J., Shrivastava, M., and Zelenyuk, A.: Evaporation kinetics and phase of laboratory and ambient secondary organic aerosol, P. Natl. Acad. Sci. USA, 108, 2190 2195, doi:10.1073/pnas.1013391108, 2011.

Vereecken, L. and Peeters, J.: A theoretical study of the $\mathrm{OH}-$ initiated gas-phase oxidation mechanism of $\beta$-pinene $\left(\mathrm{C}_{10} \mathrm{H}_{16}\right)$ : first generation products, Phys. Chem. Chem. Phys., 14, 3802 3815, doi:10.1039/c2cp23711c, 2012.

Virtanen, A., Joutsensaari, J., Koop, T., Kannosto, J., Yli-Pirilä, P., Leskinen, J., Makelä, J. M., Holopainen, J. K., Pöschl, U., Kulmala, M., Worsnop, D. R., and Laaksonen, A.: An amorphous solid state of biogenic secondary organic aerosol particles, Nature, 467, 824-827, doi:10.1038/nature09455, 2010.

Virtanen, A., Kannosto, J., Kuuluvainen, H., Arffman, A., Joutsensaari, J., Saukko, E., Hao, L., Yli-Pirilä, P., Tiitta, P., Holopainen, J. K., Keskinen, J., Worsnop, D. R., Smith, J. N., and Laaksonen, A.: Bounce behavior of freshly nucleated biogenic secondary organic aerosol particles, Atmos. Chem. Phys., 11, 8759-8766, doi:10.5194/acp-11-8759-2011, 2011.

Wang, B., Lambe, A. T., and Massoli, P.: The deposition ice nucleation and immersion freezing potential of amorphous secondary organic aerosol: Pathways for ice and mixedphase cloud formation, J. Geophys. Res., 117, D16209, doi:10.1029/2012JD018063, 2012a.

Wang, B., Laskin, A., Roedel, T., Gilles, M. K., Moffet, R. C., Tivanski, A. V., and Knopf, D. A.: Heterogeneous ice nucleation and water uptake by field-collected atmospheric particles below 273 K, J. Geophys. Res., 117, D00V19, doi:10.1029/2012JD017446, 2012b.

Wang, B., O’Brien, R. E., Kelly, S. T., Shilling, J. E., Moffet, R. C., Gilles, M. K., and Laskin, A.: Reactivity of liquid and semisolid secondary organic carbon with chloride and nitrate in atmospheric aerosols, J. Phys. Chem. A, 119, 4498-4508, doi:10.1021/jp510336q, 2015.

Yatavelli, R. L. N., Stark, H., Thompson, S. L., Kimmel, J. R., Cubison, M. J., Day, D. A., Campuzano-Jost, P., Palm, B. B., Hodzic, A., Thornton, J. A., Jayne, J. T., Worsnop, D. R., and Jimenez, J. L.: Semicontinuous measurements of gas-particle partitioning of organic acids in a ponderosa pine forest using a MOVI-HRToFCIMS, Atmos. Chem. Phys., 14, 1527-1546, doi:10.5194/acp14-1527-2014, 2014.

Yu, H., Kaufman, Y. J., Chin, M., Feingold, G., Remer, L. A., Anderson, T. L., Balkanski, Y., Bellouin, N., Boucher, O., Christopher, S., DeCola, P., Kahn, R., Koch, D., Loeb, N., Reddy, M. S., Schulz, M., Takemura, T., and Zhou, M.: A review of measurement-based assessments of the aerosol direct radiative effect and forcing, Atmos. Chem. Phys., 6, 613-666, doi:10.5194/acp-6-613-2006, 2006.

Zaveri, R. A., Easter, R. C., Shilling, J. E., and Seinfeld, J. H.: Modeling kinetic partitioning of secondary organic aerosol and size distribution dynamics: representing effects of volatility, 
phase state, and particle-phase reaction, Atmos. Chem. Phys., 14, 5153-5181, doi:10.5194/acp-14-5153-2014, 2014.

Zelenyuk, A., Imre, D., Beránek, J., Abramson, E., Wilson, J., and Shrivastava, M.: Synergy between secondary organic aerosols and long-range transport of polycyclic aromatic hydrocarbons, Environ. Sci. Technol., 46, 12459-12466, doi:10.1021/es302743z, 2012.

Sant, V., Posselt, R., and Lohmann, U.: Prognostic precipitation with three liquid water classes in the ECHAM5-HAM GCM, Atmos. Chem. Phys., 15, 8717-8738, doi:10.5194/acp-15-87172015, 2015.
Zhou, S., Lee, A. K. Y., McWhinney, R. D., and Abbatt, J. P. D.: Burial effects of organic coatings on the heterogeneous reactivity of particle-borne benzo[a]pyrene (BaP) toward ozone, J. Phys. Chem. A, 116, 7050-7056, doi:10.1021/jp3030705, 2012.

Zhou, S., Shiraiwa, M., McWhinney, R. D., Pöschl, U., and Abbatt, J. P. D.: Kinetic limitations in gas-particle reactions arising from slow diffusion in secondary organic aerosol, Faraday Discuss., 165, 391-406, 2013. 